\title{
Skill Needs of Rural Farmers' in Cassava Production and Marketing for Home Making in Ebonyi State
}

\author{
OGBA, ERNEST ITUMA Ph.D \\ Department of Technology and Vocational Education, Faculty of Education \\ Ebonyi State University, Abakaliki, Ebonyi, Nigeria \\ OKAFOR, NDU Bibian. Ph.D \\ Department of Entrepreneurship Studies, Nnamdi Azikiwe University, Awka, Anambra, Nigeria \\ REV.SR. MOUSIE, MARY AGATHA \\ Department of Home Economics, Ebonyi State University, Abakaliki, Ebonyi, Nigeria
}

\begin{abstract}
The study focused on skills for rural cassava farmers in food production and marketing for home marking in Ebonyi State. The design of the study is descriptive survey design. The population for the study was 403 , while, the sample size is 195. Four objectives and four research questions guided the study. Instrument used for the study was structured questionnaire. Cronbach alpha reliability method was used to test the internal consistency of the instrument, which yield 0.86 . The data collected was analyzed using mean with standard deviation. The findings of the study reveals that rural cassava farmers need skills for suitable land/soil for cassava cultivation, need skills for quality cassava stem. Need skills for sourcing out finance for farm operations and need skills for uprooting cassava tubers and marketing the tuber to the consumers. Based on the findings, it was recommended that rural cassava farmers should be assisted in financing farm work by government and non-governmental organizations.
\end{abstract}

Keywords: Rural, Cassava Farmers, Marketing, Tuber

DOI: $10.7176 / \mathrm{JEP} / 10-35-06$

Publication date: December $31^{\text {st }} 2019$

\section{Introduction}

The Nigerian economy Depend mainly on oil, but now, the money coming from oil is no more abundant for individual, groups, and government. However, the only promising sector of economy now is farming or Agricultural activities, to produce enough food for the country. Therefore, farmers remains at the centre stage for the needed agricultural food production to move the country forward. According to Nwankwo (2008) farmers are the men and women that can manage or operate farm work by supervising the job of farmers in day to day decision about the farm. Amed, (2014) stressed that rural farmers are group or individual that consist about, the entire population of the rural areas that involves in the production of about $95 \%$ the food consumed and fibre crops in our demostic industries in Nigeria. These group of people directly and indirectly participate in the agricultural activities in the farm as their major sources of income (Ilo, 2015). However, farmers need skills; skills according to Ibrahim (2018) is the specific ability of doing things very well. Skill according to Mayer (2002) enable young men and women to acquire the right knowledge, practical attitude, professional potentials among others that expand his horizons, and adapt to the changes in the dynamic world of production. According, to Nsiah, (2009) stress that skills assist them to remain self-reliant and make them employ others, therefore, each skill must point at a specific direction. This skills is the skill of cassava production in this study. However, the skill in rural farmers cassava production is the system of making food crop available to consumers and make farmer generate income to solve their individual and family needs UNESCO (2015) skills in cassava production, and marketing is a vocational option worthy of venturing into for income generation. Cassava farming and production is the act of developing attitude for production of cassava tuber; processing them, into different food items and selling them to generate money for the rural farmers to meet their individual needs and feed the entire nation (Kakkad 2011). The food and Agricultural organization F.A.O. (2013) maintain that energy given food item such as cassava suppose to be cheap but has increased along side with more population that demand the food item within and outside Nigeria. This high demand necessitated the need for skills development among rural cassava farmer to produce more food for export and consumption. Oke, fasina, Olusbesan (2004) meeting up with daily food supply is a problem due to shortage of food item associated with poor skills in cassava production among farmers According to Akinyemi (2012) the consequence of this is seen in the renewed cases of energy food shortage in the state. It is patinent to look beyond the consumption of food for energy supply but take advantage of cheaper and safer sources of food through little effort in soil, to bride the gap. However, Ogba, (2015) maintains that cassava, (Manihot, Esuculentum) which belong to the family of Euphorbiaceous, which has its origin from south Africa, are grown widely, in the tropics. That, cassava is the greatest nature gift to humanity and livestock for consumption as a stable food in Nigeria. Agibola, (2014) maintains that cassava stem serves as planting material, when alive or 
firewood. When dead. Its leaves are used as vegetables. Its root is eaten, as food, cassava tuber is used in production of hydrogen cyainide, flour, tapiocas, garri, laudry starch, fufu, (pounded food) alcoholic beverages): Cassava tubers are used in chemical industries for production of crylate plastics, resins and cyclic acid, (Ede, 2014). European training foundation ETF, (2019) stress that production and its skill are prominent, However, since cassava is the substitute to wheat for production of bread baking, it, need to be produced in large quantity for demostic industries to use in Nigeria and to ensure food security for nation building. Ebonyi State is one of the food basket and salt of the nation, which, their farmers, need skills for rural cassava farmers, to produce more food for income generation, export; consumption, among others, which is a welcome development and should be given serious attention it deserve. Therefore, the worries of the researchers is to identify the skills needed for rural cassava farmers for production of the food crop to meet its demand within and outside the country. Abubakar, (2015) maintains that it is necessary to emphasis, that marketing of cassava (food, items) provide a means of livehood for many families as sources of income (cash) and substantial food item kushni (2008), stress that income is the monetary gain, one makes from transaction or sells of goods and services. Income generation is the deliberate means of making money from a business, such as purchase of house hold food items, purchase of land, among others. It give an added value over other sources of food item. Marketing of food, item are lucurative in cassava products such as garri, floor, fufu, tapioca among others, which has no constraint in processing, storage, distributing and no tax is attached to it among others. Alius, (2017) stress that the marketing of cassava food items is an open window opportunity for all and sundry to cash in economy at the time families are looking for food and sources of income. Therefore, the high demand for food, items, and need to balance the Nigerian Sources of income necessitated the need to identify the skills needed for rural cassava farmers to produce more food for family survival, export, increase demostic industries among others. Therefore, the general objective of this study was to determine the skills needs of rural cassava farmer in food production and marketing for home making in Ebonyi State, specifically, the study identified theskills for

i. Selecting land/soil suitable for cultivation of cassava.

ii. Selecting quality cassava stem for planting.

iii. Skills for sourcing out finance cassava.

iv. Uprooting cassava tuber for marketing.

\section{Methodology}

Area of the Study: The design of the study is descriptive survey research design.

Population of the Study: The population for the study is 403 comprising 393 (registered rural cassava farmers and ten (10) extension agents (statistical digest 2018) in the ministry of agriculture, in Ebonyi State, Agricultural Development Programme (ESADP).

Sample for the Study: The Sample size is 195 drawn from the population, using random sampling techniques, by balloting and replacement from four (4) local government Area, out of 13 Local Government Area and four (4) communities within the Local Government Area in Ebonyi State.

Instrument for Data Collection: The instrument used for data collection was structured questionnaire. The instrument was validated by three experts, two experts from department of technology and vocational education (Agric Education unit) and one in Department of science Education (measurement and Evaluation all in faculty of Education of Ebonyi State University, Abakaliki for content and face validity respectively, corrections and observation made by the validate were used to produce the final questionnaire.

Method of Data Collection: The researcher administered 195 instrument as an on spot distribution and collected with the help of two research assistants and retrieved 159, which is $100 \%$ return.

Method of Data Analysis: The data collected was analyzed using mean and standard deviation to answer the research questions. A bench mark of 2.50 and above is needed. While below mean score bench mark of 2.50 is not needed.

Results: The results of study were obtained from the research questions answered from the data collected and analyzed. 
Table 1: Means response of respondents on skills for cassava production.

\begin{tabular}{lllll}
\hline S/N & Skills for selecting suitable land for cassava cultivation & $\bar{X}$ & SD & Decision \\
\hline 1 & Supply Fertilizer to the cassava farm. & 3.30 & 0.45 & Needed \\
2 & Supply manure to the soil farm & 3.41 & 0.48 & Needed \\
3 & Choose soil with good textures & 3.33 & 0.44 & Needed \\
4 & Choose loam soil & 3.23 & 0.43 & Needed \\
5 & Choice of clay loam soil & 3.21 & 0.45 & Needed \\
6 & Choose loam, sand soil & 2.25 & 0.43 & Needed \\
7 & Choose well aerated soil & & & Needed \\
8 & Choose loam gradual soil & 3.42 & 0.40 & Needed \\
9 & Choose clay, loam soil & 3.02 & 0.36 & Needed \\
10 & Choose loam soil (land) & 2.62 & 0.30 & Needed \\
\hline
\end{tabular}

All the item statement from 1-10 are the needed skills for selecting suitable soil for cultivating cassava crop as indicated by the respondents.

Table II: Means responses of respondents on skills for selecting quality cassava stem (input) for planting

\begin{tabular}{llcll}
\hline S/N & Skills for selecting quality cassava stem for planting cassava cultivation & $\bar{X}$ & SD & Decision \\
\hline 1 & Identify the stem that belong to TMS cassava varieties & 3.65 & 0.57 & Needed \\
2 & Select stem that produces large tubers & 3.41 & 0.56 & Needed \\
3 & Selecting stem that stay 3 months and mature for harvesting & 3.25 & 0.45 & Needed \\
4 & Select stem that its tuber do not decay easily & 3.30 & 0.46 & Needed \\
5 & Select stem that the tuber can be roasted and eaten & 3.33 & 0.38 & Needed \\
6 & Select stem that the eye buds can survive easily when planted & 3.26 & 0.46 & Needed \\
7 & Select improved stem that are alternative to wheat (bread making). & 3.32 & 0.45 & Needed \\
8 & Select cassava stem from EBADP & 3.35 & 0.43 & Needed \\
9 & Select stem that resist disease attack & 3.20 & 0.38 & Needed \\
\hline
\end{tabular}

All the item statement from 1-9 are the needed skills for selecting suitable cassava stem for planting as indicated by the respondents.

Table III: Means response of respondents on skills for sourcing out finance.

\begin{tabular}{llccc}
\hline S/N & Skills for sourcing out finance. & $\bar{X}$ & SD & Decision \\
\hline 1 & Skills for saving money for cultivating cassava & 3.48 & 0.41 & Needed \\
2 & Sells of previous years farm products in the store & 3.63 & 0.48 & Needed \\
3 & Sells of livestock in your compounds like goat, sheep, flows, among others to & 3.60 & 0.45 & Needed \\
& finance farm activities. & 3.62 & 0.44 & Needed \\
4 & Contribution of money among cassava farmers (TSUSU). & 3.63 & 0.43 & Needed \\
5 & Collection of loan from micro-finance Bank & 3.48 & 0.45 & Needed \\
6 & Collection of loan from commercial Bank & 3.49 & 0.45 & Needed \\
7 & Collection of money from their neighbour farmer & 3.50 & 0.46 & Needed \\
8 & Leasing some part of their land to other farmers and get money to finance farm & & & \\
\hline
\end{tabular}

All the item statement form 1-8 were needed skills for sourcing out finance for cassava production as indicated by the respondents

Table IV: Means response of respondent's skills for uprooting, processing and marketing tubers for farm finance.

\begin{tabular}{|c|c|c|c|c|}
\hline $\mathbf{S} / \mathbf{N}$ & Skills for uprooting, processing and marketing tubers for farm finance. & $\bar{X}$ & SD & Decision \\
\hline 1 & Harvest cassava tubers with hoe & 2.63 & 0.40 & Needed \\
\hline 2 & Poll cassava stem with two hands & 3.41 & 0.45 & Needed \\
\hline 3 & Using harvester to remove the tubers & 2.63 & 0.43 & Needed \\
\hline 4 & Level the whole heap and collect the tubers & 2.60 & 0.41 & Needed \\
\hline 5 & Cut the tuber from the stem & 3.31 & 0.45 & Needed \\
\hline 6 & Arrange tubers in basket & 3.33 & 0.46 & Needed \\
\hline 7 & Arrange the tubers in bags for sale. & 3.25 & 0.43 & Needed \\
\hline 8 & Arrange tubers in basin for sales. & 3.23 & 0.41 & Needed \\
\hline 9 & Heap the tubers on the ground for wholesale to retailers & 3.33 & 0.46 & Needed \\
\hline 10 & Pack tubers in wheel barrows for sales in the make. & 3.31 & 0.45 & Needed \\
\hline 11 & Arrange tuber in trucks for sales in market. & 2.63 & 0.41 & Needed \\
\hline 12 & Determine prices index in different measuring materials & & & Needed \\
\hline 13 & Identify different marketing princes in cassava tuber. & 3.25 & 0.43 & Needed \\
\hline 14 & Retail tubers in painters for tapioca consumers. & 3.34 & 0.46 & Needed \\
\hline
\end{tabular}


All the item statements from 1-14 were the needed skills, as indicated by the respondent in processing and marketing cassava products.

\section{Discussion of Finding}

The findings of the study in table I reveals that all the item statement (1-13) were needed by the respondents as correct skills in selecting suitable land for cassava production. This implies that land suitable for cassava production can easily be located by farmers. Since, they are varieties of land for cultivating cassava. This study in line with study of Ogba, (2014) who stress that skills, for selecting suitable land for cassava production is very crucial. Since, land is the medium for cassava growth like other plants for optimal production. The finding of this study is also in line with Kakkad (2013) who stressed, the, need for such soft skills in production capacity for selfreliance, economic generation and nation building. He viewed skills as the engine in planning for any country's development venture in technology. The findings of this study is also in line with the UNSCO (2005) who stress that skills in youth education and Adult is for economic and social policy in employment, and productivity, which gives away to poverty. The skills in cassava production to the rural farmers will go along the ways in creating job for adult and youth that are not doing anything for developing economic value, to himself and others. The findings in table two reveals that all the nine item statements were needed by the respondents as skills required in selecting cassava stem for production to ensure maximum yield. This findings are in agreement with the study of Oyetunde (2013) who maintains that farmers in Nigeria have not taken cognizance of the decrease in cassava yield over the time, because of varieties of cassava stem and Nutrient loses. That cassava requires good stem varieties for better yield after cultivation by the farmers. The findings of this study is in line with study of Ajibola (2014) who find out that selection strategy is very important in crop variety that yield well and a serious skill in production ventures. He maintain the farmers who possess such skills are bound to select good quality varieties best for-consumption and massive production of the food items. The findings of the study in table three (3) reveals that all the item statement 1-8 are in agreement, as the needed skills for sourcing out financing for cassava production. This study is in line with study of Ogba (2015) and Abua (2015) who maintains that no attention is given to cassava farmers in terms of farm financing to ensure better means of farm sponsorship for high productivity in Nigeria. The findings of this study is also in line with the study of Abubakar who stress that sources of income, as, input to the production process is an essential factors which justify the extent to which the production level, can achieve for himself and others (consumption and export). The finding of the study in table four reveals that all the item statement are in agreement with the respondents as the skills for uprooting cassava tubers and marketing the tubers to consumers. It implies that cassava tuber depends on what the consumer want to use them for, as the products in question like garri, tapioca, powder flour and fermented (fufu) among other. Abua (2015), stress that all the food items generate income. This is also in line with the study Kusirini (2008) who stress that sells of all the cassava products are lucrative and has no problem in marketing them. The findings of study is in line Aliu, S, (2017) who manutains that processing and marketing of Agricultural products start from farmers gate to finished products for distributing, storage, and sales to consumers in retails and wholesales as packaged, graded and ungrated using different price index for each measures in the market.

\section{Conclusion}

The study identify the skills needed in cassava production and marketing of its products in Ebonyi State in the South Eastern Nigeria. Based on the responses of the respondents and the result of the Analysis. The study established empirically forty five cardiac skills that farmers on cassava production will feed the teaming population, that, need them and generate income for individual, groups and government in Ebonyi State, Nigeria in general, for export, consumption for demostic industries among others.

\section{Recommendation}

1. The farmers should join hands as cooperative to financially produce more cassava food items.

2. The land allocation committee in the state, make Agricultural land in the farm settlement areas available for those who want to participate in the food production to utilize

3. That Agricultural sub-sidy in terms of fertilizers, should be given to the farmer, to boost food production and farmers need to organize themselves before the rainfall to ensure different period of cassava farming.

\section{References}

Abua, S.O. (2015) The effect of Soil properties on cassava production in costal and Hinter land Area of Southern Cross River State, Nigeria Ph.D Thesis. Department of Geography, University of Ibadan. Ibadan.

Ajibola S.O. (2014). Management strategy in fruit crop production in the $21^{\text {st }}$ Century. Journal of Agriculture 5(3) 115-1119.

Akinyeani O.R. (2012). The Contributing factors of cassava to the development of domestic industries in Nigeria. Journal of crop science 3, (1) 31-39. 
Alius, S., (2017) . Entrepreneurship Education: An overview of teacher Guide on Agricultural management Resumes 6(2) 195-210.

Amed, A.A. (2014). Rural farmers training need in Agricultural food, decline in Nigeria Journal of Agricultural Science 2(5) 16-31.

European Training foundation ETF, (2018) Human Resources as wealth of Nation: Matching skills Demand and supply-Reports. Vienna ETF.

Food and Agricultural Organization F.A.O, (2013) Annual report on food Crop Analysis in Nigeria. Desk Officer, Annual Report Ibadan.

Food and Agricultural Organization F.A.O., (2010) Stable Energy food requirement in daily body diet in Nigeria. Ibrahim, A.D. (2018) impact of Extension services in crop production. Journal of International training and Development. 14(14) 251-272.

Ilo, S.O. (2015) Women participation in Agricultural production: A Profit Analysis. Journal of Agriculture Natural Resources 7(3) 312-316.

Kusrini, O.C. (2008) financial Strength of farmers, in crop production, for Income generation in Nigeria. Journal of food Science and technology 5(3) 261-270.

Mayer, S.F. (2002) Commercial vegetable growing farmers for sustainable youth in Nigeria journal of Agricultural science 10(5) 225-301.

Nsiah, A.N. (2009) Innovative Technologies, for improved cassava production: Tuber production for food security. Journal of Teachers Perspective 7 (3) 2012.

Nwankwo, F.N. (2008). Determination of chemical composition of cassava food in Nigeria. Journal of food technology 5 (1) 451-165.

Ogba, E.I. (2014). The new Generation Agricultural Science in Secondary Schools Enugu. Immaculate Publisher.

Oke, Fasina, Olughesan, (2014), The Constraints in Cassava Production in African. Journal of Crop Production 5(2) 265-270

Oyetunde R.N. (2013) cassava Micro and macro nutrient up take in supporting portioning alley cropping, as influenced by Glomusspp-in sub-tropic. Agricultural Science Journal 5(15) 140-148.

UNESCO (2005) Youth, Education skills and employment for poverty and social policy Team. Economic and social policy Division. 